\title{
Orolingual and abdominal angioedema post thrombolysis and thrombectomy
}

Charline Benoit, MD, Marie Cantier, MD, Christine Rodriguez-Régent, MD, Olivier Gout, MD, and Michael Obadia, MD

Neurology ${ }^{\circledR}$ 2018;90:140-141. doi:10.1212/WNL.0000000000004834
Correspondence

Dr. Benoit

charlinebenoit5@gmail.com

\section{Figure 1 Imaging}

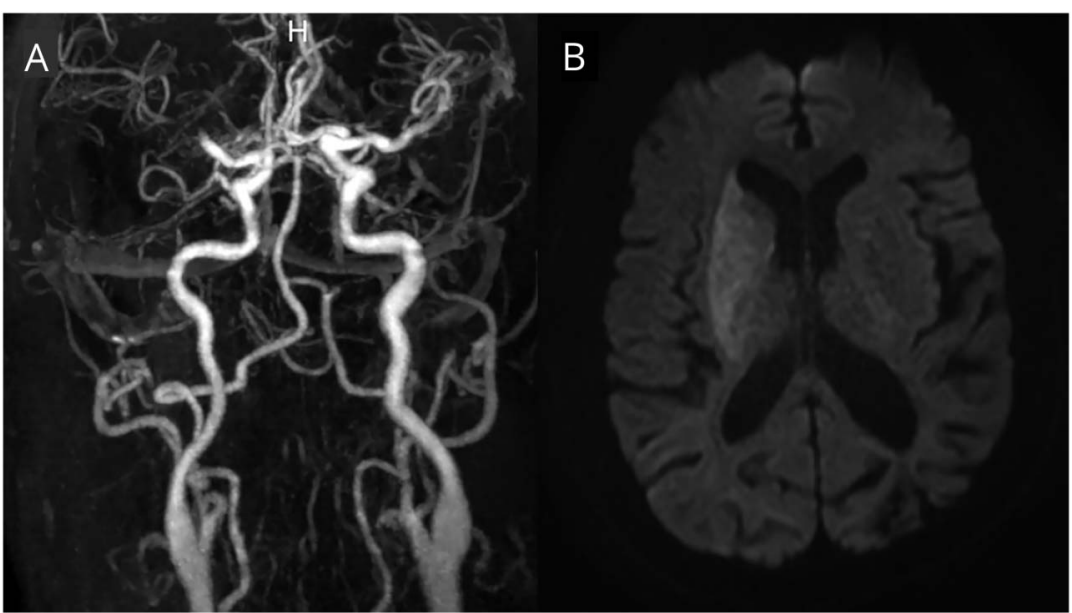

(A) Magnetic resonance angiography shows right proximal occlusion of the middle cerebral artery. (B) Diffusion-weighted axial MRI shows right deep middle cerebral artery infarct.

A 53-year-old man treated with an angiotensin-converting enzyme (ACE) inhibitor presented with left hemiplegia (NIH Stroke Scale 23). Magnetic resonance angiography revealed a right proximal middle cerebral artery occlusion (figure 1). Thirty minutes after thrombolysis, orolingual swelling was observed. Two hours later, just after mechanical thrombectomy was completed, he developed painful abdominal edema, which improved after icatibant administration (figure 2). Bradykinin-mediated angioedema can be a complication of recombinant tissue plasminogen activator, typically orolingual, with increased risk for patients on ACE inhibitors. ${ }^{1}$ We speculate that the procedure of thrombectomy, acting as a mechanical stress, ${ }^{2}$ could have been a triggering factor for the unusual presentation of abdominal edema.

\section{Author contributions}

Dr. Benoit: study concept and design. Dr. Cantier: analysis and interpretation. Dr. RodriguezRégent: analysis and interpretation. Dr. Olivier Gout: analysis and interpretation. Dr. Obadia: study supervision.

\section{Study funding}

No targeted funding reported.

\section{Disclosure}

The authors report no disclosures relevant to the manuscript. Go to Neurology.org for full disclosures.

\section{References}

1. Myslimi F, Caparros F, Dequatre-Ponchelle N, et al. Orolingual angioedema during or after thrombolysis for cerebral ischemia. Stroke 2016;47:1825-1830.

2. Aygören-Pürsün E, Martinez Saguer I, Kreuz W, Klingebiel T, Schwabe D. Risk of angioedema following invasive or surgical procedures in HAE type I and II the natural history. Allergy 2013;68:1034-1039. 
Figure 2 Left asymmetric upper and lower lips angioedema and abdominal painful edema

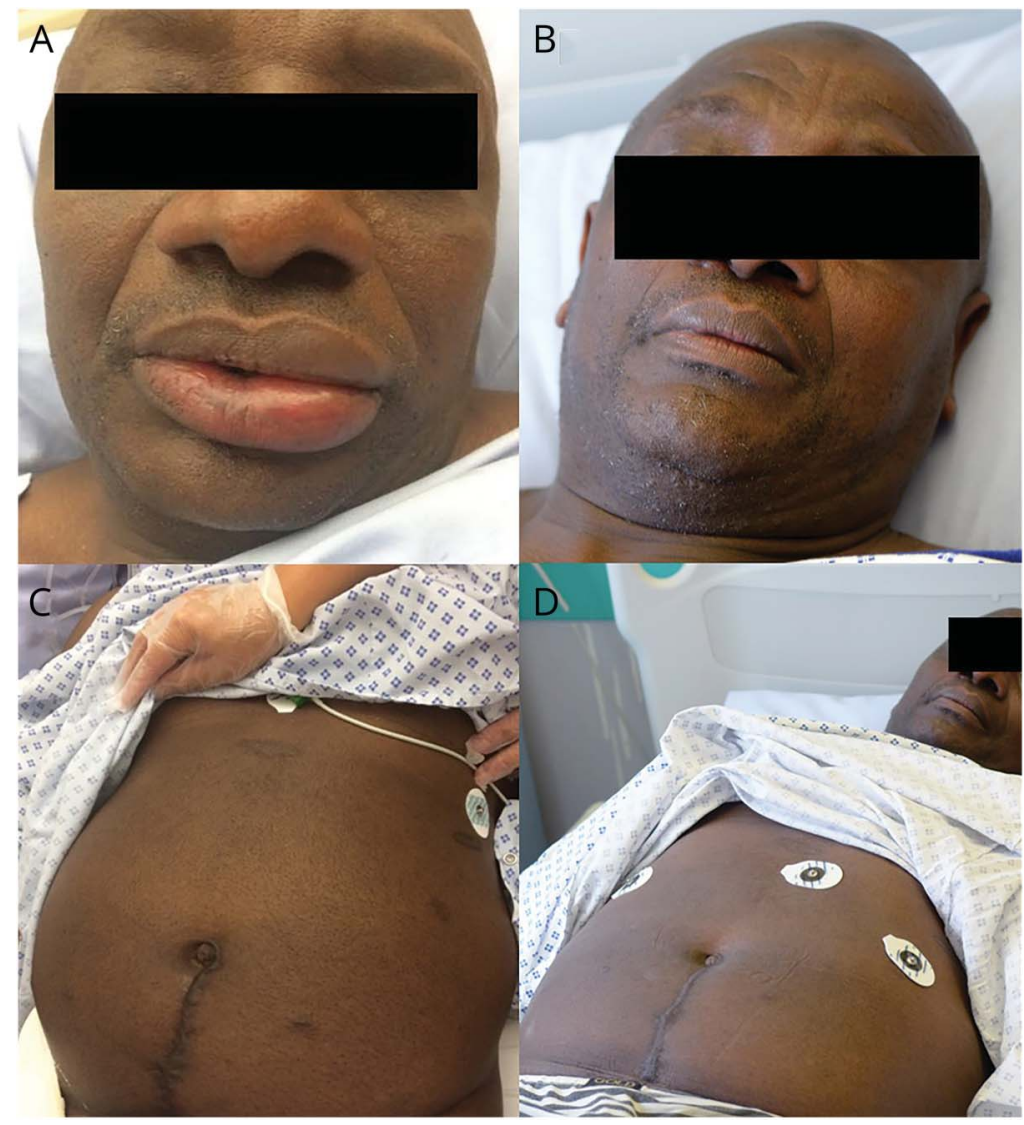

Left asymmetric upper and lower lips angioedema, contralateral to right hemispheric ischemia $(A)$, and abdominal painful edema (C), both regressing after icatibant administration $(B, D)$.

\section{Visit the Neurology ${ }^{\circledR}$ Website at Neurology.org/N}

- More article-based content on home pages

- Streamlined menus and navigation

- Enhanced blog sections for specialty areas

- Same experience on desktop, tablet, and mobile devices

- Audio summaries of current issues

- Improved article reading experience; links more evident (pdf, analytics, social media)

- Neurology ${ }^{\circledR}$ Clinical Practice initiative "Practice Current" global surveys will be accessible across sites

f Find Neurology ${ }^{\circledR}$ on Facebook: http://tinyurl.com/neurologyfan

Follow Neurology $y^{\circledR}$ on Twitter: https://twitter.com/GreenJournal 


\section{Neurology}

\section{Orolingual and abdominal angioedema post thrombolysis and thrombectomy Charline Benoit, Marie Cantier, Christine Rodriguez-Régent, et al. Neurology 2018;90;140-141 \\ DOI 10.1212/WNL.0000000000004834}

\section{This information is current as of January 15, 2018}

\section{Updated Information \&} Services

References

Subspecialty Collections

Permissions \& Licensing

Reprints including high resolution figures, can be found at: http://n.neurology.org/content/90/3/140.full

This article cites 2 articles, 1 of which you can access for free at: http://n.neurology.org/content/90/3/140.full\#ref-list-1

This article, along with others on similar topics, appears in the following collection(s):

All Cerebrovascular disease/Stroke

http://n.neurology.org/cgi/collection/all_cerebrovascular_disease_strok

Critical care

http://n.neurology.org/cgi/collection/critical_care

Information about reproducing this article in parts (figures,tables) or in its entirety can be found online at:

http://www.neurology.org/about/about_the_journal\#permissions

Information about ordering reprints can be found online:

http://n.neurology.org/subscribers/advertise

Neurology $®$ is the official journal of the American Academy of Neurology. Published continuously since 1951, it is now a weekly with 48 issues per year. Copyright Copyright ( 2018 American Academy of Neurology. All rights reserved. Print ISSN: 0028-3878. Online ISSN: 1526-632X.

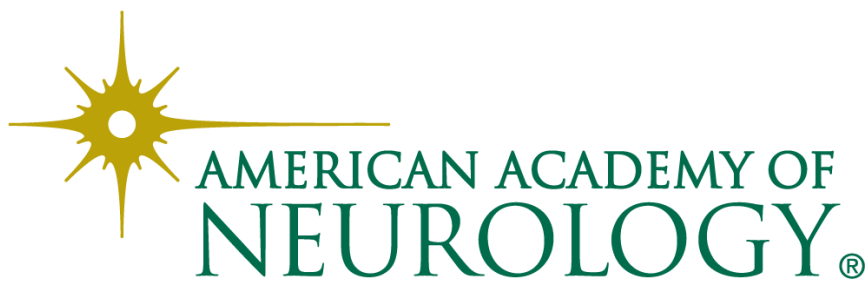

